\title{
THE DIFFERENCE IN THE TOTAL CHOLESTEROL/HDL-C RATIO IN TYPE-2 DM PATIENTS WITH DIABETIC ULCERS AND WITHOUT DIABETIC ULCERS IN BETHESDA HOSPITAL YOGYAKARTA
}

\section{PERBEDAAN RASIO KOLESTEROL TOTAL/HDL-C PASIEN DM TIPE 2 DENGAN ULKUS DAN TANPA ULKUS DIABETIKUM DI RUMAH SAKIT BETHESDA YOGYAKARTA}

\author{
Devina Sagitania ${ }^{* *}$, Purwoadi Sujatno ${ }^{2}$ Fenty $^{3}$ \\ ${ }^{1}$ Faculty of Medicine, Duta Wacana Christian University, Dr. Wahidin Sudiro Husodo \\ Street No. 5-25 Yogyakarta 55224, Indonesia \\ ${ }^{2}$ Bethesda Hospital, Jendral Sudirman Street No. 70, Kotabaru, Gondokusuman, \\ Yogyakarta, Indonesia \\ ${ }^{3}$ Faculty of Pharmacy, Universitas Sanata Dharma, Campus 3 Paingan, Maguwoharjo, Depok, \\ Sleman, Yogyakarta 55282, Indonesia
}

Received July 28, 2017; Accepted May 23, 2018

\begin{abstract}
Diabetes mellitus (DM) is one of the diseases that annually shows an increase. An increase of DM prevalence will follow the increasing diabetic ulcers complication. Cholesterol could influence to create ulcer through atherosclerosis process. Ratio of total cholesterol/HDL is an important predictor to detect early risk of vascular complication in type 2 DM patients that can manifest as diabetic ulcers. This study aims to know whether there is any difference in the Total Cholesterol/HDL-C Ratio in type-2 DM patients with diabetic ulcers and without diabetic ulcers. This study was an analytic observational with cross-sectional approach. Data collection was done using the purposive sampling with a sample size of 30 patients of diabetes mellitus with diabetic ulcers and 30 patients without diabetic ulcers. The data were analyzed by Mann-Whitney. The median results in Total cholesterol/HDL-C ratio between Type-2 DM patients with diabetic ulcers and without diabetic ulcers were 6.025 and 3.680 respectively. The median of cholesterol total/HDL-C ratio Type-2 DM patients with diabetic ulcers was higher than those without diabetic ulcers. Mann-Whitney showed the value of $P=0.000$, so that this study found a significant difference. In conclusion, the ratio of total cholesterol/HDL-C in type-2 DM patients with diabetic ulcer was significantly higher than type-2 DM patients without diabetic ulcers in Bethesda Hospital, Yogyakarta.
\end{abstract}

Keywords: diabetic ulcers, $H D L$, total cholesterol, type-2 diabetes mellitus

\begin{abstract}
ABSTRAK
Diabetes melitus (DM) merupakan salah satu penyakit yang setiap tahun menunjukkan adanya peningkatan. Peningkatan prevalensi DM tentunya akan diikuti dengan peningkatan komplikasi ulkus diabetikum. Kolesterol dapat berpengaruh dalam terjadinya ulkus diabetikum melalui proses aterosklerosis. HDL memiliki peran penting dalam mencegah aterosklerosis. Rasio kolesterol total terhadap HDL merupakan prediktor yang penting untuk mendeteksi dini risiko komplikasi vaskular yang dapat bermanifestasi menjadi ulkus. Penelitian ini bertujuan untuk mengetahui apakah terdapat perbedaan rasio kolesterol total terhadap HDL pada pasien DM tipe 2 dengan ulkus diabetikum dan pasien DM tipe 2 tanpa ulkus diabetikum di RS Bethesda
\end{abstract}

*Corresponding author: Devina Sagitania

Email:dsagitania17@gmail.com 
Yogyakarta. Penelitian ini merupakan penelitian observasional analitik dengan pendekatan cross sectional. Pengambilan data menggunakan purposive sampling dengan besar sampel sebanyak 30 pasien DM dengan ulkus diabetikum dan 30 pasien DM tanpa ulkus diabetikum. Data dianalisis dengan uji mann-whitney. Median Rasio Kolesterol total/HDL antara pasien DM tipe 2 dengan ulkus diabetikum dan tanpa ulkus diabetikum sebesar 6,025 dan 3,680. Pasien DM tipe 2 dengan ulkus memiliki rasio kolesterol/hdl lebih tinggi dibanding tanpa ulkus. Uji Mann-Whitney menunjukkan nilai $p=0,000$ sehingga penelitian ini didapatkan perbedaan yang bermakna. Kesimpulannya adalah, rasio kolesterol total/HDL pada penderita DM tipe 2 dengan ulkus lebih tinggi secara bermakna dibandingkan dengan penderita DM tipe 2 tanpa ulkus diabetikum di RS. Bethesda Yogyakarta.

Kata kunci: ulkus diabetikum, HDL, kolesterol total, diabetes mellitus tipe 2

\section{INTRODUCTION}

Diabetes mellitus (DM) is one of the diseases that shows an increasing trend annually. International Diabetes Federation (IDF 2014) stated that the number of DM patients of 366 million in 2011 increased to 387 million in 2014. Similar conditions also occur in Indonesia, according to the Basic Health Research Report (Kementrian Kesehatan Republik Indonesia, 2013), the prevalence of DM patients in 2013 (2.1\%) increased from $1.1 \%$ in 2007 with the highest incidence rate in Yogyakarta Province $(2.6 \%)$.

Increased incidence rates of DM will definitely be followed by an increased risk of long-term complications, which are divided into micro vascular and micro vascular. Micro vascular complications may include retinopathy, nephropathy, and neuropathy, caused by capillary and small blood vessel damage. Macro vascular complications are an illustration of the increased risk of atherosclerosis formation, in the form of coronary artery disease (CAD), cerebrovascular injury (CVA), and peripheral vascular disease (PAD) (Cagliero, 2016).

One of the most common complications of diabetes is diabetic ulcers. Diabetic ulcers are partial damage (partial thickness) or full damage (full thickness) of the skin that can extend into tissues under the skin, tendons, muscles, bones and joints that occur in the legs of a person with diabetes mellitus (Tarwoto, 2012). The prevalence of diabetic ulcer patients in Indonesia is around $15 \%$. The case of diabetic ulcers is often the result of late manifestations of peripheral neuropathy, Peripheral Arterial Disease (PAD) or a combination of both (Brownrigg et al., 2012).

Diabetic ulcers are often closely related to one of the macro vascular complications of DM, namely Peripheral Arterial Disease (PAD) (Rodrigues and Mitta, 2011). Peripheral arterial disease (PAD) is a condition of blockage of blood flow in peripheral blood vessels that can be caused by the process of atherosclerosis (American Diabetes Association, 2015). The blockage may cause oxygenation to the peripheral part, causing ischemia resulting in an ulcer on the foot of a DM patient, and the prolonged wound healing in the lower limb (Jeffrey et al., 2016).

The process of atherosclerosis in a DM ulcer is similar to that of a coronary heart disease. The process of atherosclerosis may occur due to lipid fraction abnormalities, such as decreased HDL, or increased total cholesterol, LDL, and triglycerides (Perkumpulan Endokrinologi Indonesia, 2015). High density of lipoprotein (HDL) plays an important role in reducing the risk of atherosclerosis because it has antiatherogenic processes, whereas total cholesterol plays a role in increasing the process of atherosclerosis because it has an atherogenic process (Jesus et al 2009).

The ratio of total cholesterol / HDL cholesterol is obtained by dividing the total amount of cholesterol by HDL. The ratio of total cholesterol / HDL cholesterol according to NCEP ATP III should be $<4.5$ in men and 
$<4.0$ in women. The higher the level, the more it will accelerate the process of atherosclerosis, when the blood vessels of the extremities are affected, causing the occlusion of blood vessels and ischemic that may lead to ulcers.

Based on the description, this study is important to know whether there is a difference in the ratio of total cholesterol / HDL between type-2 DM patients who have foot ulcer complications and type-2 DM patients without diabetic foot ulcer complications.

\section{METHODS}

\section{Research Design and Subject}

The type of this research is an observational analytical research with crosssectional approach. The data collection using secondary data in the form of medical record employed a purposive sampling technique with a large sample of $30 \mathrm{DM}$ patients with diabetic foot ulcer complication and $30 \mathrm{DM}$ patients without diabetic foot ulcer complication at Bethesda hospital, Yogyakarta. The inclusion criteria of this study were all type-2 DM patients with ulcers and without ulcers who have total cholesterol and HDL data. The exclusion criterion for this study is a medical record that has incomplete data.

Data processing was done at the Center for CE \& BU Study using IBM SPSS 22 program. Normality test was done first using the Shapiro-Wilk test. The difference in the ratio of total cholesterol / HDL in type-2 DM patients with ulcers and without ulcers was analyzed using the Mann-Whitney test.

\section{RESULTS AND DISCUSSION}

The subjects in this study were 30 type- 2 DM patients with ulcer complications, and 30 type-2 DM patients without ulcer complications, having characteristic features as shown in Table I.

In the comparative tests, the total cholesterol, HDL cholesterol, and the ratio between them among the 30 type-2 DM patients with ulcers and 30 type 2 DM patients without ulcers will be compared. Table II shows the median of the total desired cholesterol levels according to NCEP ATP ( $<200 \mathrm{mg} / \mathrm{dl}$ ) for the type-2 DM patients with ulcers and those without ulcers. The total cholesterol levels in type-2 DM patients with ulcers were higher than those without ulcer, i.e. $183.35 \mathrm{mg} / \mathrm{dl}$ and $177.50 \mathrm{mg} / \mathrm{dl}$, but the difference was not significant because $\mathrm{p}=$ $0.679(\mathrm{p}>\alpha)$. This is similar to the retrospective study conducted in Saudi Arabia by Manda et al., 2012, which found higher total cholesterol levels in DM patients with ulcers, i.e. $189.89 \mathrm{mg} / \mathrm{dl}$, compared to those without ulcers, i.e. $175.75 \mathrm{mg} / \mathrm{dl}$ and both levels were categorized as desirable according to NCEP ATP III ( $<200 \mathrm{mg} / \mathrm{dl})$, although the results were different although insignificant.

The results of this study also showed a significant decrease $(p=0.000)$ of the High Density Lipoprotein (HDL) levels in type-2 DM patients with ulcers, as shown in Table II that the median of the HDL values was about $29.65 \mathrm{mg} / \mathrm{dl}$, whereas the median in type-2 diabetes mellitus patients without ulcers was higher, at about $48.00 \mathrm{mg} / \mathrm{dl}$. The results of this study are similar to the prospective cohort studies conducted in India by Mohammad, et al. (2012) on 162 DM patients without ulcers and 162 DM patients with ulcers. The study found a decrease in HDL in DM patients with ulcers, with the mean of HDL values at around $34.6 \mathrm{mg} / \mathrm{dl}$. The DM patients without ulcers had a higher mean of HDL at about $44.3 \mathrm{mg} /$ $\mathrm{dl}$, with a significant difference of $(\mathrm{p}=0.005)$.

Although the median of the total cholesterol levels of the type-2 DM patients with ulcers and without ulcers was included in the desired category ( $<200 \mathrm{mg} / \mathrm{dl}$ ) according to NCEP-ATP III, it would remain a high risk if the HDL levels decreased from the normal level, since the ratio of total cholesterol to HDL increased. In the study conducted by Dionyssiou et al., in Greece in 2002, the total cholesterol did not differ significantly, and only a significant decrease in HDL could increase the ratio between the two in DM patients with lower limb occlusive disease caused by the atherosclerosis process. 
Table I. Basic Characteristics of the Research Subjects Based on the Diabetic Ulcers and Non-Diabetic Ulcers

\begin{tabular}{|c|c|c|}
\hline Characteristics & Type-2 DM patients with ulcers & $\begin{array}{c}\text { Type-2 DM patients without } \\
\text { ulcers }\end{array}$ \\
\hline \multicolumn{3}{|l|}{$\operatorname{Sex}(\%)$} \\
\hline Male & $13(43.3 \%)$ & $5(16.7 \%)$ \\
\hline Female & $17(56.7 \%)$ & $25(83.3 \%)$ \\
\hline Age (Year) & $55.50(28-77)^{*}$ & $55.50(35-86) *$ \\
\hline$>50$ years old $(\%)$ & $22(73.33 \%)$ & $23(76.67 \%)$ \\
\hline$<50$ years old $(\%)$ & $8(26.67)$ & $7(23.33 \%)$ \\
\hline Total Cholesterol (mg/dL) & $183.35(79.7-328.2)^{*}$ & $177.50(96.7-260.3)^{*}$ \\
\hline High & $4(13.33 \%)$ & $8(26.67 \%)$ \\
\hline Borderline & $8(26.67 \%)$ & $3(10 \%)$ \\
\hline Desired & $18(60 \%)$ & $19(63.33 \%)$ \\
\hline $\mathrm{HDL}(\mathrm{mg} / \mathrm{dL})$ & $29.65(5.60-49.50)^{*}$ & $48.00(33.20-69.70)^{*}$ \\
\hline $\begin{array}{l}\text { Ratio of Total Cholesterol /HDL } \\
(\mathrm{mg} / \mathrm{dL})\end{array}$ & $6.025(3.44-43.30)^{*}$ & $3.680(2.20-5.45)^{*}$ \\
\hline Abnormal LDL (\%) & $13(43.33 \%)$ & $22(73.33 \%)$ \\
\hline Hypertriglyceride (\%) & $16(53.33 \%)$ & $8(26.67)$ \\
\hline $\begin{array}{l}\text { Pre-prandial blood sugar level } \\
(\mathrm{mg} / \mathrm{dL})\end{array}$ & $228(122-322)^{*}$ & $176.65(74.10-351.00)^{*}$ \\
\hline $\begin{array}{l}\text { Random blood glucose } \\
\text { level }(\mathrm{mg} / \mathrm{dL})\end{array}$ & $262.0(137.40-675.0)^{*}$ & $222.0(79.00-414.0)^{*}$ \\
\hline $\begin{array}{l}\text { blood glucose levels } 2 \text { hours post } \\
\text { prandial }(\mathrm{mg} / \mathrm{dL})\end{array}$ & $265.50(87.00-513.60)^{*}$ & $227.35(84.00-488.70)^{*}$ \\
\hline Hypertension (\%) & $20(66.67 \%)$ & $15(50 \%)$ \\
\hline
\end{tabular}

Tabel II. Mann-Whitney Statistical Test on Type-2 DM Patients with Ulcers and Without Ulcers

\begin{tabular}{cccc}
\hline \multirow{2}{*}{ Characteristics } & \multicolumn{2}{c}{ Type-2 DM } & p-value \\
\cline { 2 - 3 } $\begin{array}{c}\text { Total Cholesterol } \\
(\mathrm{mg} / \mathrm{dL})\end{array}$ & $183.35(79.70-328.20)$ & $177.50(96.70-260.30)$ & 0.679 \\
\hline HDL $(\mathrm{mg} / \mathrm{dL})$ & $29.65(5.60-49.50)$ & $48.00(33.20-69.70)$ & 0.000 \\
\hline $\begin{array}{c}\text { Ratio of Total } \\
\text { Cholesterol/HDL } \\
(\mathrm{mg} / \mathrm{dL})\end{array}$ & $6.025(3.44-43.30)$ & $3.680(2.20-5.45)$ & 0.000 \\
\hline
\end{tabular}

HDL and total cholesterol cannot be self-assessed based merely on the high or normal classification of cholesterol levels. Both must be assessed to get the ratio value. The National Cholesterol Education Program (NCEP, 2001) also recommends that total cholesterol measurement be included in HDL measurements (Chen et al., 2016). The effect of decreased HDL cholesterol levels on the risk of atherosclerosis will be greater than the increase in total cholesterol (Ikura et al., 2015).

The total acceptable cholesterol/ HDL ratio according to NCEP ATP III is $<4.5 \mathrm{mg} /$ $\mathrm{dl}$ for men and <4 mg / dl for women. In Table II, the results of this study found a significant difference in total cholesterol / HDL ratio $(\mathrm{p}=$ $0.000)$ between type-2 DM patients with ulcer and those without ulcers. The median in the ratio of total cholesterol / HDL of type $2 \mathrm{DM}$ patients with ulcers was $6.025 \mathrm{mg} / \mathrm{dL}$, whereas patients without ulcers had an acceptable ratio median of about $3.680 \mathrm{mg} / \mathrm{dL}$.

A variety of simple indices involving cholesterol, the ratio of total cholesterol / HDL known as the Castelli I index is the strongest predictor for the risk of vascular complications, as it reflects the overall balance 
between atherogenic and antiatherogenic (Jesus et al., 2009). This finding is corroborated by the research of Jiang et al., 2004, which, after 6 years of monitoring, found that the ratio of total cholesterol / HDL was the best predictor of vascular complications compared to LDL or other lipid profiles in type-2 DM patients. Cross-sectional studies, conducted by Olamoyegun et al., 2016 in Nigeria with 699 subjects, also proved that the ratio of total cholesterol / HDL (the Castelli I index) was a better predictor of vascular complications than other lipids, with the value of $(\mathrm{p}<0.001)$.

Peripheral arterial disease (PAD) and peripheral vascular disease are the most common processes of diabetic ulcers, due to prolonged duration of wound healing and amputations in DM patients (Rodrigues and Mitta, 2011). The high ratio of total cholesterol / HDL affects the incidence of diabetic ulcers via PAD resulting from the process of atherosclerosis, with a mechanism similar to the formation of atherosclerosis in cardiovascular disease. The cohort study, conducted by Mounier et al., in 2007, found a significant increase in the ratio of total cholesterol / HDL in the PAD study subjects. It proved the importance of the role of the Castelli I index (total cholesterol / HDL) in PAD incidence caused by atherosclerosis.

A study was conducted in Taiwan by Te et al., in 2007, to monitor the type-2 DM patients for 3 years. The ratio of total cholesterol / HDL was also the most important independent predictor for changes in the value of ABI (Anckle Brachial Index), the high ratio of total cholesterol / HDL can predict a decrease in brachial ankle index in the subject of type-2 Asian DM patients. It highlights the role of the ratio of total cholesterol / HDL to decrease blood circulation in the extremities.

Although the results of the total cholesterol levels are optimal, but if the HDL is low, the ratio between the two will increase and the risk of atherosclerosis increases, considering that HDL has anti-atherosclerotic effect. Part of the atheroprotective effect is associated with the transport of excess cholesterol deposited in the blood vessels to the liver (Bleda et al., 2012). The effects of antioxidants inhibit the oxidation of cholesterol in the blood vessels. HDL also plays a role in protecting endothelial function, which increases NO (nitric oxide) which plays a role in vasodilation, and reduces expression of intracellular adhesion molecule (ICAM) -1 and E-selection, an IL-8 cytokine that increases the binding of leukocytes to atheroma formation. Endothelial apoptosis is also known to be prevented by HDL (Ahn and Kim, 2016).

Low HDL levels will cause a decrease in endothelial protection, resulting in endothelial dysfunction, accumulation of cholesterol in the blood vessels; and causing atherosclerosis. If the formation of atherosclerosis occurs in peripheral blood vessels (in this case lower extremities), it will cause PAD, marked by blood vessel occlusion, and will cause stenosis, a condition where blood and oxygen supply to tissues in the lower extremity will be impaired, marked by the loss or decrease in pulse in the dorsal pedic, tibial, and popliteal arteries. The patient's legs experience atrophy and coldness; and nails thicken due to ischemic, resulting in the condition of ulcers in the foot that usually starts from the tip of the toe and the ulcer healing process will be disrupted if oxygen supply remains inadequate (Schaper et al., 2012).

Increased incidence of diabetes mellitus is usually followed by the complication of diabetic mellitus ulcers in the community. Therefore, it is important to assess and evaluate the risk factors. It is possible to improve early prevention strategies and early risk assessments. Regular lipid level checks can be performed to prevent undesirable conditions. The examination of total cholesterol should always be accompanied by HDL examination, to control the ratio between the two cholesterol levels. This is to detect earlier the ratio of total cholesterol to abnormal HDL which is a risk factor of type-2 DM complications, in this case diabetic ulcers. This research should still be developed to obtain more valid and tested data. Development of this research can be done by 
using primary data samples or using other more accurate research methods.

The limitation of this study is that it does not consider other factors that can interfere with the results. These factors are the patients' duration in suffering from $\mathrm{DM}, \mathrm{HbA}$ c levels as the sign of controlled diabetes, use of fatlowering drugs, menopause-related sex factors, socio-demographic and economic factors, as these factors may affect the results of the study. Lipid levels are strongly influenced by lifestyle, diet, level of patients' education in the diet and foot care recommended by doctors and health workers who are responsible for the patients' diets.

\section{CONCLUSION}

There was a significant difference of in the total cholesterol / HDL ratio between type2 DM patients with diabetic ulcers and type-2 DM patients without diabetic ulcers in Bethesda Hospital. The ratio of the total cholesterol / HDL in type-2 DM patients with diabetic ulcers is significantly higher than type-2 DM patients without diabetic ulcers.

\section{REFERENCES}

Ahn, N. and Kim, K., 2016. High-density lipoprotein cholesterol (HDL-C) in cardiovascular disease: effect of exercise training. Integrative Medicine Research, 5, 212-215.

American Diabetes Association, 2015. Diabetes Care. Standards of Medical Care in Diabetes.

Bleda, S., de Haro, J., Varela, C., Esparza, L., Rodriguez, J., and Acin, F., 2012. Improving Total-Cholesterol/HDL-

Cholesterol Ratio Results in an Endothelial Dysfunction Recovery in Peripheral Artery Disease Patients. Journal of Cholesterol. 2012, 895326.

Brownrigg, J.R., Davey, J., Holt, P.J., Davis, W.A., Thomson, M.M., Ray, K.K., and Hinchliffe, R.J., 2012. The Association of Ulceration of the Foot with Cardiovascular and All-cause Mortality in Patients with Diabetes: A Meta-Analysis. Diabetalogia, 55 (11), 2906-2912.
Cagliero, E., 2016. Diabetes and Long Term Complications. In: Jameson, J., Grott, L., Kretser D. 7th ed. Endocrinology: Adult and Pediatric. Philadelphia, PA: Elsevier Saunders.

Chen X., Zhou L., and Hussain M., 2016. Lipids and Dyslipoproteinemia. In: McPherson. Henry's Clinical Diagnosis and Management by Laboratory Methods. Philadelphia, PA: Elsevier Saunders.

Dionyssiou-Asteriou, A., Papastamatiou, M., Vatalas, I.A., and Bastounis, E., 2002. Serum Apolipoprotein AI Levels in Atherosclerotic and Diabetic Patients. European Journal of Vascular and Endovascular Surgery, 24(2) 161-165.

Ikura, K., Hanai, K., Shinjyo, T., and Uchigata, Y., 2015. HDL cholesterol as a predictor for the incidence of lower extremity amputation and wound-related death in patients with diabetic foot ulcers. Atherosclerosis. 239 (2), 465-469.

Jeffrey, A., Kalish, M.D., and Frank B., 2016. Diabetic Foot Problems. In: John, W. Comprehensive Vascular and Endovascular Surgery. Philadelphia, PA: Elsevier Saunders.

Jiang, R., Schulze, M. B., and Hu, F.B. 2004., Non-HDL cholesterol and apolipoprotein b predict cardiovascular disease events among men with type 2 diabetes. Diabetes Care.

Ikura, K., Hanai, K., Shinjyo, T., and Uchigata, Y., 2015. HDL cholesterol as a predictor for the incidence of lower extremity amputation and wound-related death in patients with diabetic foot ulcers. Atherosclerosis. 239 (2), 465-469.

Kementrian Kesehatan Republik Indonesia, 2013, Riset Kesehatan Dasar 2013 [online]. Ministry of Health Republic of Indonesia. Available from: http://www.depkes.go.id/resources/down load/general/Hasil\%20Riskesdas\%2020 13.pdf [Accessed 27 June 2017].

Manda, V., Sreedharan. J., Muttappallymyalil, J., Das, R., and Hisamatsu, E., 2012. Foot ulcers and risk factors among diabetic patients visiting Surgery Department in a University Teaching 
Hospital in Ajman, UAE. International Journal of Medicine and Public Health, 2(3), 34-38.

Millán, J., Pintó, X., Muñoz, A., Zúñiga, M., Rubiés-Prat, J., Pallardo, L.F., Masana, L., Mangas, A., et al., 2009. Lipoprotein ratios: Physiological significance and clinical usefulness in cardiovascular prevention. Vascular Health and Risk Management, 5, 757-765.

Mohammad, Z., Abida, M., and Jamal, A. 2012. Plasma adiponectin, IL-6, hsCRP, and TNF- $\alpha$ levels in subject with diabetic foot and their correlation with clinical variables in a North Indian tertiary care hospital. Indian Journal of Endocrinology and Metabolism, 16(5), 769-7.

Mounier, V.C., Stephan, D., and Aboyans, V. 2007. The best of vascular medicine in 2006. Arch Mal Coeur Vaiss, 100, 47-55.

NCEP-ATP III, 2001. Executive Summary of the Third Report of the National Cholesterol Education Program (NCEP) Expert Panel on Detection, Evaluation, and Treatment of High Blood Cholesterol In Adults (Adult Treatment Panel III). JAMA, 285, 2486- 2497.

Olamoyegun, M.A., Oluyombo, R., and Asaolu, S.O., 2016. Evaluation of dyslipidemia, lipid ratios, and atherogenic index as cardiovascular risk factors among semi-urban dwellers in Nigeria. Annals of African Medicine, 15(4), 194199.

Perkumpulan Endokrinologi Indonesia, 2015. Panduan Pengelolaan Dislipidemia di Indonesia 2015. Jakarta: PB. Perkeni.

Rodrigues, J. and Mitta, N., 2011. Diabetic Foot and Gangrene [online]. IntechOpen. Available from: https://www.intechopen.com/books/gangr ene-current-concepts-and-managementoptions/diabetic-foot-and-gangrene [Accessed 27 June 2017].

Schaper, N.C., Andros, G., Apelqvist, J., Bakker, K., Lammer, J., Lepantalo, M., Mills, J.L., Reekers, J., Shearman, C.P., Zierler, R.E., and Hinchliffe, R.J., 2012. Diagnosis and treatment of peripheral arterial disease in diabetic patients with a foot ulcer. Aprogress report of the International Working Group on the Diabetic Foot. Diabetes Metab Research and Review, 28(Suppl 1), 218-224.

Tarwoto, 2012. Keperawatan Medikal BedahGangguan Sistem Endokrin. CV Trans Info Media. DKI Jakarta. 